\title{
REACTION OF NATIVE FRUIT TREES FROM BRAZILIAN AMAZON TO Meloidogyne enterolobii
}

\section{REAÇÃO DE FRUTÍFERAS NATIVAS DA AMAZÔNIA BRASILEIRA A Meloidogyne enterolobii}

\author{
Eduardo José de ALMEIDA ${ }^{1}$ \\ Jaime Maia dos SANTOS ${ }^{2}$ \\ Antonio Baldo Geraldo MARTINS ${ }^{3}$ \\ Gleina Costa Santos ALVES ${ }^{4}$
}

\begin{abstract}
This research was conducted in a greenhouse from Department of Fitossanity at São Paulo State University, Jaboticabal, SP, to evaluate the reaction of four Amazon's native fruits tree species ["Abiu" (Pouteria caimito), "Araça Pera" (Psidium acutangulum), "Camu-camu" (Myrciaria dubia) and "Bacuri" (Platonia insignis)] and one from Central America, Sapodilla (Achras zapota) to the root-knot nematode Meloidogyne enterolobii Yang \& Eisenback, 1983 (Meloidogynidae: Heteroderidae). Seedlings of each fruit trees averaging 12 months of age were planted in ceramic pots containing autoclaved soil and sand. They were inoculated, with addition of $10 \mathrm{~cm}^{3}$ of 400 eggs and $\mathrm{J} 2$ in suspension per $\mathrm{cm}^{3}$ to the root system, with a total initial population (IP) of 4000 eggs and $\mathrm{J} 2$ of $M$. enterolobii. The nematode population was obtained from roots of guava tree (Psidium guajava) in the city of Vista Alegre do Alto, SP. The assessment was carried out after 150 days at inoculation with the recovery and counting of the final nematode population (FP) in the root system of the fruit trees. The reaction of the fruit species was given by the factor of nematode reproduction (RF) according to the equation FP / IP, where $\mathrm{RF}>1$ was considered susceptible and RF $<1$, resistant. The "Araça Pera" was susceptible to $M$. enterolobii and the others fruits plant were not favorable host to $M$. enterolobii. This study reports the first infection in $P$. acutangulum by $M$. enterolobii in greenhouse conditions.
\end{abstract}

Key-words: Reproduction factor; root-knot; resistance, Amazon fruit trees.

\section{RESUMO}

O presente experimento foi conduzido em casa de vegetação do Departamento de Fitossanidade da UNESP/FCAV Campus de Jaboticabal, SP, objetivando avaliar a reação de quatro espécies de frutíferas nativas da Amazônia [Abieiro (Pouteria caimito), Araçazeiro Pêra (Psidium acutangulum); Camu-camuzeiro (Myrciaria dubia) e Bacuparizeiro (Platonia insignis)] e uma da América Central [Sapotizeiro (Achras zapota)] ao nematoide de galhas Meloidogyne enterolobii yang \& Eisenback, 1983 (Meloidogynidae: Heteroderidae). Mudas das frutíferas com 12 meses de idade foram plantadas em vasos de cerâmica, com capacidade de 6 litros, contendo terra e areia autoclavados. Em seguida foram inoculadas com $10 \mathrm{~cm}^{3}$ da suspensão de 400 ovos e $\mathrm{J} 2$ por $\mathrm{cm}^{3}$ no sistema radicular, totalizando uma população inicial (Pi) de 4000 ovos e $\mathrm{J} 2$ de $M$. enterolobii. A população do nematoide foi obtida de raízes de goiabeira (Psidium guajava) na cidade de Vista Alegre do Alto, SP. A avaliação ocorreu 150 dias após a inoculação com a recuperação e contagem da população final (Pf) do nematoide no sistema radicular das frutíferas. A reação das espécies frutíferas se deu pelo fator de reprodução do nematoide (FR) de acordo com a equação Pf / Pi, em que FR $>1$, considerado suscetível e FR $<1$, resistente. O Araçazeiro Pêra foi suscetível a $M$. enterolobii e as demais frutíferas não se mostraram hospedeiras favoráveis a esse nematoide. Esse trabalho consiste no primeiro relato de infecção de Araçazeiro Pêra por M. enterolobii em condições de casa de vegetação no Brasil.

Palavras-chave: Fator de reprodução; nematoide de galha; resistência, frutíferas da Amazônia.

\footnotetext{
1- FAPESP Post-Doctoral. Department of Fitosanity, Faculty of Agrarian and Veterinarian Sciences, University of São Paulo State, Access road Prof. Paulo Donato Castellane, w/n. 14884-900. Jaboticabal, SP, Brazil. E-mail: eduardo.almeida@fcav.unesp.br.

2- Department of Fitosanity D.Sc. Faculty of Agrarian and Veterinarian Sciences, University of São Paulo State, Jaboticabal, SP, Brazil. E-mail: jmsantos@fcav.unesp.br.

3 - Department of Vegetal Production D.Sc. Faculty of Agrarian and Veterinarian Sciences, University of São Paulo State, Jaboticabal, SP, Brazil. E-mail:baldo@fcav.unesp.br

4- D,Sc Student, Federal University of Goiás, Goiânia, Brazil. E-mail: gleinacosta@yahoo.com.br
} 


\section{INTRODUTION}

The cultivation of fruits has been growing in the brazilian economy and, because of the increase in cultivated areas, it is common the establishment of new pests and diseases. According to Carvalho \& Nascimento (2004), the Brazilian Amazon have about 220 species of plants that produce edible fruit, which represents $44 \%$ of Brazil's native fruit diversity. These fruits can be tasted fresh, as juices, jams, ice creams, liqueurs and candy.

Regarding native fruits, there is a significative number of species with high commercial potential as "Bacuri" (Platonia insignis Mart.), "Abiu" [Pouteria caimito (Ruiz \& Pav.) Raldk.], "Camu-camu" [Myrciaria dubia (Humb., Bonpl. \& Kunth) McVaugh], the Mirtaceae plants (Psidium spp.), among others (Carvalho \& Nascimento, 2004). However, the production of fruit trees could be higher if not for its sanity plant problems, especially related to nematodes. Among the pathogens species that are common to most fruit are: Meloidogyne incognita and $M$. javanica, Pratylenchus semipenetrans, $P$. vulnus, Radophulus similis, Mesocriconema xenoplax and Helicotylenchus multicinctus (Rossi, 2002).

The nematode $M$. enterolobii Yang \& Eisenbach, 1983 (Sin.: M. mayaguensis Rammah \& Hirschmann, 1988) is highly polyphagous, infecting fruit tree, oleraceous, soybean, sugarcane, ornamental and weed (Almeida et al., 2008). This nematode has been causing considerable losses to guava (Psidium guajava L.) crops. According to Ferraz \& Lot (2007), in the last two decades, the Brazilian Northeast region was eradicated at least $50 \%$ of production area in Pernambuco State. Carneiro et al. (2007) reported that in the irrigated perimeter of Petrolina, PE, and Juazeiro, BA, Brazil, there were a reduction of up to $75 \%$ in areas with guava culture, from 6000 ha in 2000 to 1668 ha in 2006, forcing producers to open new croplands into native vegetation.

The present study aimed to assess the reaction of four fruit tree species from Amazon region and one from Central America to nematode $M$. enterolobii.

\section{MATERIAL AND METHODS}

The experiment was conducted in a greenhouse from Plant Sanity Department of Agrarians and Veterinarians Sciences Faculty - São Paulo State University, municipality of Jaboticabal, São Paulo, Brazil. Four Amazon's fruit tree species were tested: "Abiu" (Pouteria caimito), "Araça Pera" (Psidium acutangulum), "Camu-camu" (Myrciaria dubia) and "Bacuri" (Platonia insignis); and one from Central America: Sapodilla (Achras zapota).

Fruit trees were propagated by seeds germinated in plastic bags $(11 \times 22 \mathrm{~cm})$ filled with a substrate containing underground soil and sand, previously checked for nematodes presence. Seedlings with one year age were transplanted to ceramic pots (6 liters), containing soil and sand (2:1 proportion) autoclaved, and kept in a greenhouse.

The $M$. enterolobii inoculum was collected from roots of a guava ( $P$. guajava) orchard in the municipality of Vista Alegre do Alto, São Paulo, Brazil. The nematode identification occurred in the photonic microscope with morpho-anatomical study of females and males, and confirmed by the study of esterase isozyme phenotype (Carneiro et al., 2000). The suspension of $M$. enterolobii was obtained using the technique of Hussey \& Barker (1973). Eggs counting and second stage juveniles (J2) was held in Peter chamber, with the aid of photonic microscope and adjusted to 400 eggs and $\mathrm{J} 2$ per $\mathrm{cm}^{3}$. Inoculation of roots occurred two months after transplanting to pots, through the addition of $10 \mathrm{~cm}^{3}$ of the suspension, which formed an initial population (IP) of 4000 eggs and J2 per pot, distributed in six small holes in the substrate surrounding the plant's root system.

To measure the inoculum viability, the same procedure was carried out with 'Santa Cruz Kada' tomato (Solanum lycopersicum L.) in a similar substrate. The experimental design was completely randomized with five replications, consisting of one pot each. The pots with inoculated plants were kept in a greenhouse with daily irrigation.

Tomato trees were evaluated 60 days after inoculation, and the fruit trees were evaluated after 150 days. During the assessments, plant's roots were collected and taken to the laboratory where the extraction of the nematodes was carried out by the method of Hussey \& Barker (1973). Then, all forms of the nematode were counted in Peter chamber under photonic microscope knowing final population (FP). The reproduction factor (RF) was calculated, and it is defined by the ratio FP / IP (Oostenbrink, 1966). Plants with RF $<1$ were considered resistant, and therefore they are not favorable for hosting the nematode, while exhibiting RF > 1 were susceptible, thus favorable to host the nematode.

\section{RESULTS AND DISCUSSION}

All fruit trees species studied in this research, except the "Araça Pera", obtained a RF $<1$, what demonstrated that they were not an adequate host to nematode (Table 1). The tomatoes proved of the viability of inoculum with $\mathrm{RF}=12,2,60$ days after inoculation.

There are no reports in the world literature about $M$. enterolobii associated to these Amazonian native fruits, consisting this research the first record of infection by $M$. enterolobii in "Araça Pera" in a greenhouse condition. Carneiro et al. (2001) firstly recorded this pathogen in Petrolina, PE, Curaçá and Maniçoba, BA, Brazil, causing severe damages on 
TABLE 1. Reaction of fruits species to a population of Meloidogyne enterolobii.

\begin{tabular}{|c|c|c|}
\hline Species & No Galls $^{\text {RF }}$ \\
\hline Tomato (Solanum lycopersicum) & $>100$ & 12,2 \\
\hline Araça Pera (Psidium acutangulum) & 24,50 & 3,00 \\
\hline Abiu (Pouteria caimito) & 11,30 & 0,20 \\
\hline Sapodilla (Achras zapota) & 15,30 & 0,30 \\
\hline Camu-camu (Myrciaria dubia) & 14,30 & 0,13 \\
\hline Bacuri (Platonia insignis) & 13,20 & 0,50 \\
\hline
\end{tabular}

$\mathrm{N}^{\circ}$ Galls $=$ Average number of galls and $\mathrm{RF}=$ reproduction factor

commercial planting of guava. This recent record can justify the small amount of research on this nematode in fruit trees.

The Sapodilla was not an adequate host for $M$. enterolobii, which agrees with Coimbra et al. (2006) who analyzed samples of rhizosphere and sapodilla roots and did not found species of Meloidogyne in their roots and rhizosphere, or even significant amounts of other key plant parasites in the plants analyzed.

Several species of the Mirtaceae family such as guava are reported as susceptible to $M$. enterolobii (Carneiro et al., 2001), segregating varieties of Mirtaceae plant ( $P$. guineense) (Maranhão et al., 2003), Araça (Psidium sp.) Jaboticaba (Myrciaria cauliflora), Jaboticabal Guava's ( $P$. guajava cv. Minor), Pitanga (Eugenia uniflora) (Almeida, 2008). However, in this study the "Araça boi" (E. stipitata) was classified as resistant and this data disagree with the verbal information of Silva (2009), which reported that the "Araça boi" was found severely infected with $M$. enterolobii, in Pará State, Brazil. These data suggest the hypothesis that there may be physiological differences between the populations of the nematode.

For management of plant diseases, is indicated, among other strategies, the prevention of entrance of the patogens in field. However, in areas where there are reports of the nematodes, the eradication is unpractical. In infested areas, the management of the nematode aiming the coexistence of the pathogen at low levels in soil and plant or crop species or resistant varieties is a viable alternative. $\mathrm{Li}$ ma et al. (2005) and Carneiro et al. (2006) recorded this nematode in environments of native vegetation of the Atlantic Forest in Rio de Janeiro and Parana, Brazil, indicating that it is a peculiar kind of Brazilian biomes. Thus it is necessary to search for non-host fruit to $M$. enterolobii as an alternative to the producers.

The "Abiu", "camu-camu", "Bacupari" and Sapodilla were resistant to $M$. enterolobii and "Araça Pera" was susceptible according to reproduction factor.

\section{ACKNOWLEDGMENTS}

To the "Fundação de Amparo a Pesquisa do Estado de São Paulo" (FAPESP) for granting aid to research that promoted the accomplishment of this work.

To the "Coordenação de Aperfeiçoamento de Pessoal de Nível Superior" (CAPES) for scholarships.

\section{REFERENCES}

1. ALMEIDA, E. J. et al. Novos Registros sobre Meloidogyne mayaguensis no Brasil e Estudo Morfológico Comparativo com M. incognita. Nematologia Brasileira, v. 32, n. 3, p. 236-241, 2008.

2. ALMEIDA, E. J. O nematóide de galha da goiabeira (Meloidogyne mayaguensis Ramah \& Hirschmann, 1988): identificação, hospedeiros e ação patogênica sobre goiabeiras. 2008. 98 f. Tese (Doutorado em Produção Vegetal), Faculdade de Ciências Agrária e Veterinárias / Universidade Estadual Paulista, Jaboticabal, 2008.

3. CARNEIRO, R. G. et al. Identificação de Meloidogyne mayaquensis em goiabeira e em plantas invasoras, em solo argiloso, no Estado do Paraná. Nematologia Brasileira, v. 30, n. 3, p. 293-298, 2006.

4. CARNEIRO, R. M. D. G. et al. Enzime phenotype of Meloidogyne spp. population. Nematology, v. 2, p. 645-654, 2000.

5. CARNEIRO, R. M. D. G. Impacto de novas espécies de Meloidogyne na agricultura. In: Congresso Brasileiro de Nematologia, 27., 2007, Goiânia. Resumos... Goiânia: UFG, 2007. 36-34.

6. CARNEIRO, R. M. D. G. et al. Primeiro registro de Meloidogyne mayaguensis em goiabeira no Brasil. Nematologia Brasileira, v. 25, n. 2, p. 223-228, 2001.

7. CARVALHO, J. E. U.; NASCIMENTO, W. M. O. Fruticultura na Amazônia: o longo caminho entre a domesticação e a utilização. 2004. Disponível em: http://www.esalq.usp.br/departamentos/lpv/download/Resumo\%20Palestra\%20Esalq.pdf Acesso: 19 maio 2009. 
ALMEIDA, E. J. et al. Reaction of native fruit...

8. COIMBRA, J. L. et al. Nematóides fitoparasitos associados a fruteiras nativas e exóticas na Região do Recôncavo da Bahia, Brasil. Magistra, v. 18, n. 1, p. 48-51, 2006.

9. FERRAZ, J. V.; LOT, L. Boas perspectivas para fruta de mesa. In: NEHMI, I. M. D.; FERRAZ, J. R.; NEHMI FILHO, V. A.; SILVA, M. L. M. (Coords.) Anuário da Agricultura Brasileira. OESP, São Paulo, São Paulo, 2007. p. 340-344.

10. HUSSEY, R. S.; BARKER, K. R. A comparison of methods collecting inocula of Meloidogyne spp. including a new technique. Plant Disease Reporter, v. 57, n. 12, 1025-1028, 1973.

11. LIMA, I. M.; SOUZA, R. M; SILVA, C. P.; CARNEIRO, R. M. D. G. Meloidogyne sp. from preserved areas of Atlantic Forest in the state of Rio de Janeiro. Nematologia Brasileira, Brasília, v. 29, n. 1, p. 31-38, 2005.

12. MARANHÃO, S. R. V. L. et al. Reação de indivíduos segregantes de araçazeiro a Meloidogyne incognita Raça 1, M. javanica e M. mayaguensis. Nematologia Brasileira, v. 27, n. 2, p. 173-178, 2003.

13. OOSTENBRINK, M. Major characteristics of the relation between nematodes and plants. Mededelingen Van De landbouwhogeschool Te Wageningen, v. 66, n. 4, p. 1-46, 1966.

14. ROSSI, C. E. Nematóides em fruteiras. In: Reunião itinerante de fitossanidade do Instituto Biológico, v. 7, Indaiatuba, São Paulo, p. 5-23, 2002.

15. SILVA, G. S. Maranhão University State (2009), Verbal Information.

Recebido em 07/06/2010

Aceito em 05/12/2011 